\title{
THE EFFECTIVENES OF E-LEARNING AS A LEARNING MEDIA IN ARCHIVING SUBJECT AT SMKN 2 BUDURAN SIDOARJO DURING THE COVID-19 PANDEMIC
}

\author{
Yuni Maulidiyah Dwi Fajar ${ }^{1}$, Durinda Puspasari ${ }^{2}$ \\ 1,2 Pendidikan Administrasi Perkantoran, Universitas Negeri Surabaya, Indonesia \\ ${ }^{1}$ yuni.17080314083@mhs.unesa.ac.id, ${ }^{2}$ durindapuspasari@unesa.ac.id
}

\begin{abstract}
This study aimed to analyze the effectiveness of e-learning as a learning media for archiving subjects at SMKN 2 Buduran Sidoarjo in the covid-19 pandemic. This study was qualitative research. Data were collected through interviews and questionnaires. The validity of data was examined by source triangulation. Then, the data were analyzed by the Miles and Huberman Model, namely data collection, data reduction, data presentation, and conclusions. The results showed that e-learning learning media was effectively utilized in the archiving subject, based on 4 indicators of learning effectiveness. In terms of the elearning quality, which was seen from the process and results, it was found that 2 applications used during the learning process, namely google classroom and whatsapp was easily accessed and understood. In addition, the students' learning outcomes, which was scored more than 80 (72.6\%); described the student' and teachers' readiness in starting the lessons and the ongoing process of learning, such as the fulfillment of facilities like cellphones and laptops, after that, the teachers provided materials for students to learn first. Moreover, in terms of incentives, the teachers' activities whcih motivated students every time they started the lessons included giving advices and positive energy; the teachers provided additional score for active students. Then, in terms of time, it was seen from the presence of teacher to start the lesson on time in which the teachers assigned students based on the predetermined deadlines so that the students were more disciplined.
\end{abstract}

Keywords: effectiveness; e-learning; learning media

\section{EFEKTIVITAS E-LEARNING SEBAGAI MEDIA PEMBELAJARAN MATA PELAJARAN KEARSIPAN DI SMKN 2 BUDURAN SIDOARJO PADA ERA PANDEMI COVID 19}

\begin{abstract}
ABSTRAK
Tujuan penelitian ini adalah untuk menganalisis efektivitas e-learning sebagai media pembelajaran mata pelajaran kearsipan di SMKN 2 Buduran Sidoarjo pada era pandemi covid-19. Penelitian ini merupakan penelitian kualitatif. Teknik pengumpulan data yaitu wawancara dan angket. Keabsahan data menggunakan triangulasi sumber. Teknik analisis data menggunakan Model Miles dan Huberman yaitu pengumpulan data, reduksi data, penyajian data, dan penarikan kesimpulan. Hasil penelitian menunjukkan bahwa pembelajaran melalui e-learning pada mata pelajaran kearsipan kelas X OTKP 1 di SMKN 2 Buduran Sidoarjo sudah berjalan efektif berdasarkan 4 indikator efektivitas pembelajaran: dari segi kualitas pembelajaran, dapat dilihat dari proses dan hasil dalam pembelajaran kearsipan menggunakan 2 aplikasi yaitu google classroom dan whatsapp yang mudah diakses dan dipahami. Hasil belajar siswa yang mendapatkan nilai lebih dari 80 sebesar 72,6\%; dari segi kesesuaian tingkat pembelajaran, dapat dilihat dari kesiapan siswa dan guru pada saat akan memulai pelajaran dan berlangsungnya proses pembelajaran kearsipan seperti terpenuhinya sarana dan prasarana yaitu hp dan laptop, guru memberikan materi untuk dipelajari terlebih dahulu oleh siswa; dari segi insentif, dapat dilihat dari aktivitas guru dalam memberikan motivasi pada siswa kelas X OTKP 1 di SMKN 2 Buduran Sidoarjo setiap akan memulai pelajaran dan berlangsungnya pembelajaran dengan memberikan nasihat dan energi positif, guru juga memberikan nilai tambahan kepada siswa yang aktif; dari segi waktu, dapat dilihat dari kehadiran guru untuk memulai pelajaran kearsipan dengan tepat waktu, guru memberikan tugas sesuai deadline yang sudah ditentukan agar siswa lebih disiplin.
\end{abstract}

Kata Kunci: efektivitas; e-learning; media pembelajaran

\begin{tabular}{|c|c|c|}
\hline Submitted & Accepted & Published \\
\hline 20 April 2021 & 19 Juli 2021 & 28 Juli 2021 \\
\hline
\end{tabular}

\begin{tabular}{|l|c|r|r|}
\hline Citation & $:$ & $\begin{array}{r}\text { Fajar, Y.M.D., \& Puspasari, D. (2021). The Effectivenes ef E-Learning as a Learning Media in Archiving Subject at SMKN } \\
\text { 2 Buduran Sidoarjo during the Covid-19 Pandemic. Jurnal PAJAR (Pendidikan dan Pengajaran), 5(4), 1043-1064. } \\
\text { DOI : http://dx.doi.org/10.33578/pjr.v5i4.8403. }\end{array}$ \\
\hline
\end{tabular}

\section{PENDAHULUAN}

Indonesia kini tengah dihadapkan dengan pandemi covid-19 yang tidak kunjung selesai. Coronavirus Disease 2019 atau sering disebut dengan covid-19 merupakan suatu virus jenis baru yang dapat menular. Berdasarkan pernyataan
World Health Organization (WHO), covid-19 ini pertama kali ditemukan di Wuhan, Tiongkok, pada bulan Desember 2019 (World Health Organization, 2020). Penularan virus ini sangat cepat hingga beberapa kasus meninggal dunia 
dikarenakan terkena covid-19. WHO mengatakan bahwa penularan virus ini disebabkan karena keluarnya percikan air dari mulut dan hidung dari seseorang yang telah terpapar covid-19 (World Health Organization, 2020). Sehingga apabila percikan air tersebut menempel di berbagai permukaan di sekitarnya yang mengakibatkan orang sehat telah menyentuh benda yang sudah terinfeksi dapat terpapar virus covid-19. Akibatnya kurang dari 6 bulan virus ini telah menyebar ke beberapa negara di dunia salah satunya di Indonesia. Tidak hanya di bidang ekonomi, sosial, dan teknologi, namun bidang pendidikan pun juga terdampak dengan adanya pandemi covid-19 ini.

Banyak upaya yang telah dilakukan oleh pemerintah untuk warga Indonesia selamat dari wabah penyakit mematikan ini. Salah satunya pada bidang pendidikan, upaya yang dilakukan pemerintah adalah dengan merubah proses belajar mengajar yang awalnya dilakukan dengan pembelajaran offline menjadi pembelajaran secara online. Hal ini berarti kegiatan pembelajaran dilakukan di rumah atau dikenal dengan kebijakan Work From Home (WFH) atau Belajar dari Rumah (BDR). Prinsip dari kebijakan Belajar dari Rumah (BDR) yaitu diharapkan siswa mampu untuk mengakses pelajaran atau materi secara lebih mudah dan bebas tanpa adanya batasan ruang dan waktu. Kegiatan tersebut diharapkan mampu memudahkan siswa dan guru dalam melaksanakan pembelajaran sehingga kegiatan pembelajaran akan tetap dilaksanakan di tengah pandemi covid19. Data dari Kementerian Pendidikan dan Kebudayaan tahun 2020 bahwa banyaknya siswa yang terdampak covid-19 sehingga mengharuskan mereka belajar di rumah yaitu Sekolah Dasar dan Sederajat sebanyak 28,6 juta, Sekolah Menengah Pertama dan Sederajat sebanyak 13,1 juta, Sekolah Menegah Atas dan Sederajat sebanyak 11,3 juta, dan Pendidikan Tinggi sebanyak 6.3 Juta (Kemendikbud, 2020). Dari sekian banyak siswa yang terdampak pandemi covid-19 ini, pembelajaran harus tetap dilaksanakan walaupun ada berbagai kekurangan atau keterbatasan yang dihadapi. Pembelajaran tersebut dilakukan melalui e-learning. Aktivitas belajar dari rumah sering disebut dengan pembelajaran daring (dalam jaringan) atau e-learning. E-learning atau Elektronic Learning diharapkan dapat mengatasi permasalahan pendidikan di Indonesia pada saat adanya pandemi covid- 19 .

E-learning merupakan pembelajaran tanpa adanya batas ruang dan waktu dengan menggunakan jasa elektronika sebagai media pembelajaran. Efendi (2005) berpendapat bahwa materi pembelajaran dapat didownload secara bebas sebagai sumber referensi pembelajaran. Menurut Wahyuddin \& Nurcahaya (2019), elearning merupakan suatu pemanfaatan dengan memakai jaringan internet dalam pembelajaran. Senada dengan Rohmawati (2015) yang menyampaikan bahwa e-learning merupakan mode komunikasi asinkron dan sinkron untuk pembelajaran dengan menggunakan media elektronik. Hasil penelitian yang dilakukan oleh Panigrahi, Srivastava, \& Panigrahi (2020) menyatakan bahwa e-learning telah berhasil diterapkan di dunia akademis dan industri dengan peningkatan kualitas pengajaran dan pembelajaran yang dilaporkan dan meningkatkan pendapatan, hasil belajar dan kepuasan. Penelitian Chien (2012) menjelaskan bahwa faktor sistem dan infrastruktur memiliki pengaruh positif pada efektivitas e-learning. Hasil penelitian Hapsari \& Fitria (2020) menunjukkan bahwa e-learning sudah efektif dalam mencapai tujuan pembelajaran, serta pembelajaran efektif dapat tercapai ketika sistem lebih terstruktur. Hasil penelitian yang dilakukan Hanum (2013) juga menunjukkan bahwa dalam pelaksanaan pembelajaran e-learning sesuai dengan standar mutu pelaksanaan e-learning dan cukup efektif. Sehingga pembelajaran melalui e-learning ini diharapkan mampu mencapai tujuan pembelajaran sesuai dengan kualitas pembelajaran dengan sistem yang lebih terstruktur agar mampu memudahkan proses pembelajaran pada saat pandemi covid-19.

Kelebihan dari penggunaan e-learning adalah mampu meningkatkan kemampuan siswa untuk memiliki wawasan yang lebih luas, hal ini disebabkan beberapa materi pelajaran yang ada pada e-learning biasanya belum tentu tersedia dalam media cetak seperti buku yang sering digunakan dalam proses pembelajaran (Setiaji \& 
Jumadi, 2018); dapat diakses dengan mudah menggunakan smartphone atau laptop yang bisa digunakan di manapun dan kapanpun (Nurhidayat, 2020); meningkatkan efektivitas waktu yang digunakan dalam kegiatan pembelajaran sehingga tidak memerlukan waktu yang lama untuk belajar (Ravitz \& Blazevski, 2014). Dalam penerapan $e$ learning diperlukan proses pembelajaran yang efektif agar dapat mewujudkan tujuan pembelajaran sehingga mampu mencapai efektivitas pembelajaran yang baik. Adanya $e$ learning peserta didik tidak harus menyimak secara langsung perkataan guru di ruang kelas, namun e-learning dapat mempersingkat waktu belajar dan dapat digunakan di manapun tanpa harus berada di ruang kelas (Lutfiyah \& Sulisawati, 2019). Hasil penelitian Zahra \& Wijayanti (2020) mengatakan bahwa manfaat menggunakan e-learning yaitu sebagai suplemen (tambahan) dikarenakan siswa dapat memilih materi sehingga dapat memanfaatkan dan mendapatkan pengetahuan yang luas, sebagai komplemen (pelengkap) yaitu dapat melengkapi materi saat pembelajaran berjalan, serta substitusi (pengganti) yaitu siswa dapat mengelola kegiatan belajar sesuai dengan waktu dan aktivitas yang fleksibel. Efektivitas e-learning dalam pembelajaran dipengaruhi oleh 4 indikator menurut Slavin (2008), yaitu kualitas pembelajaran, kesesuaian tingkat pembelajaran, insentif, dan waktu.

SMKN 2 Buduran Sidoarjo merupakan salah satu sekolah menengah kejuruan negeri di kota Sidoarjo yang memiliki 6 program keahlian, yaitu Otomatisasi dan Tata Kelola Perkantoran (OTKP), Akuntansi dan Keuangan Lembaga (AKL), Bisnis Daring dan Pemasaran (BDP), Multimedia (MM), Perbankan dan Keuangan Mikro (PKM), Rekayasa Perangkat Lunak (RPL). Program keahlian Otomatisasi dan Tata Kelola Perkantoran (OTKP) terdapat mata pelajaran kearsipan yang merupakan salah satu mata pelajaran yang tercantum dalam struktur kurikulum 2013 revisi yang diberikan pada siswa kelas X OTKP 1 di SMKN 2 Buduran Sidoarjo. Mata pelajaran kearsipan merupakan mata pelajaran inti di program keahlian Otomatisasi Tata Kelola dan Perkantoran. Kearsipan penting untuk dipelajari karena merupakan pelajaran yang berkaitan dengan pengarsipan dokumen dan dengan mempelajari mata pelajaran kearsipan siswa dapat belajar untuk menempatkan dan mengelola dokumen dengan rapi. Untuk itulah diperlukan adanya strategi yang tepat dalam proses pembelajaran mata pelajaran kearsipan terutama pada era pandemi covid 19. Sebelum adanya pandemi covid 19 ini SMK Negeri 2 Buduran Sidoarjo memiliki sistem e-learning sendiri karena terdapat beberapa guru yang masih kurang bisa menerapkan pembelajaran melalui $e$ learning dengan baik akibat kurang mampu menjalankan teknologi yang lebih terbaru dan kurangnya pelatihan yang diberikan oleh pihak SMKN 2 Buduran Sidoarjo yang mengakibatkan kendala dalam menerapkan pembelajaran $e$ learning. Pada era pandemi covid 19 ini pembelajaran pada mata pelajaran kearsipan kelas $\mathrm{X}$ OTKP 1 yang diterapkan di SMKN 2 Buduran Sidoarjo tetap dilakukan melalui e-learning berupa Whatsapp sebagai media komunikasi antara guru dan siswa; Google Classroom sebagai media untuk memberikan materi serta penugasan maupun ulangan yang diberikan oleh guru kepada siswa. Dalam proses pembelajarannya SMKN 2 Buduran Sidoarjo ini menerapkan kurikulum 2013 revisi. Menurut Arisendy \& Puspasari (2021), tujuan kurikulum 2013 adalah agar peserta didik lebih aktif, produktif, menginovasi dan kreatif dalam proses belajar. Oleh karena itu kurikulum 2013 tepat digunakan agar dapat meningkatkan keaktifan dan kemandirian siswa. Adapun tujuan penelitian ini adalah untuk menganalisis efektivitas e-learning sebagai media pembelajaran mata pelajaran kearsipan di SMKN 2 Buduran Sidoarjo pada era pandemi covid-19.

\section{KAJIAN TEORETIS Belajar}

Belajar adalah idealisme berarti suatu kegiatan psiko-fisik-sosio menuju perkembangan pribadi seutuhnya. Oleh karena itu dalam belajar dapat diperlihatkan melalui tingkah laku atau aktivitas yang menunjukkan keaktifan seseorang (Suprijono, 2009). Menurut Purwanto (2002), belajar merupakan suatu proses kegiatan yang tidak nyata dan tidak dapat dilihat. Suatu proses 
tersebut terjadi pada dalam diri seseorang yang sedang mengalami proses belajar. Belajar merupakan suatu perubahan tingkah laku yang menetap pada diri seseorang sebagai hasil pengalaman. Menurut Pane \& Dasopang (2017), belajar ialah sesuatu sistem yang termuat dalam proses pendidikan, serta pendidikan terdiri dari sebagian komponen yang terhubung satu sama lain. Terdiri dari guru, siswa, tujuan, modul, media, tata cara, serta penilaian. Penelitian yang dilakukan Rustiani, et al (2019) menyatakan bahwa suatu kegiatan belajar dikatakan baik apabila terus berusaha menjadi lebih baik sehingga hasil yang didapatkan seseorang akan menjadi optimal. Sebaliknya walaupun seseorang dikatakan belajar, tetapi tidak mau berusaha menjadi lebih baik berarti aktivitas belajar tersebut tidak secara nyata kalau dirinya melaksanakan aktivitas belajar.

Sehingga dapat disimpulkan bahwa belajar merupakan proses perubahan tingkah laku, yang pada mulanya seorang anak tidak dibekali dengan kemampuan, setelah terbentuknya proses belajar maka anak tersebut mengalami perubahan tingkah laku serta pemahamannya menjadi terus bertambah.

\section{Pembelajaran}

Pendidikan memiliki tujuan dalam mengembangkan karakter pada diri seseorang dan cara yang dapat dilakukan yaitu melalui proses pembelajaran, oleh karena itu menurut Susanto (2013), pembelajaran yakni suatu kegiatan untuk mendidik siswa agar dapat belajar serta memiliki karakter dengan baik agar mampu menumbuhkan serta mengembangkan pengetahuan. Pembelajaran adalah kegiatan dalam proses membimbing serta mengarahkan peserta didik dalam melakukan proses belajar (Pringgawidagda, 2002). Menurut Yohana, Muzakir, \& Dina (2020), pembelajaran merupakan suatu proses mengatur siswa untuk menumbuhkan dalam melakukan proses belajar. Oleh karena itu dalam belajar diperlukan adanya perubahan sedangkan dalam pembelajaran diperlukan pengaturan agar tercapainya kegiatan siswa di sekolah. Karwati (2014) juga mendefinisikan bahwa pembelajaran merupakan usaha seorang guru untuk mengarahkan peserta didik dalam proses belajar agar tujuan dapat tercapai. Oleh karena itu dengan adanya interaksi antara guru dan siswa diharapkan dapat menghasilkan pembelajaran yang efektif. Dalam pembelajaran diperlukan beberapa komponen agar terlaksana dengan baik yang terdiri dari pendidik, peserta didik, materi, tujuan, media, metode dan evaluasi (Pane \& Dasopang, 2017). Oleh karena itu komponen pembelajaran tersebut saling terhubung, apabila salah satu komponen tidak dipergunakan maka akan mempengaruhi proses pembelajaran menjadi tidak efektif.

Sehingga dapat disimpulkan bahwa pembelajaran diperankan oleh dua orang atau lebih yaitu siswa dan guru. Dalam prosesnya sebagai guru yaitu mengajar sedangkan siswa yaitu belajar. Oleh karena itu pembelajaran pada dasarnya adalah aktivitas terstruktur yang memberikan rangsangan kepada seseorang agar dapat belajar dengan baik sehingga pembelajaran dapat efektif dilaksanakan.

\section{E-learning}

E-learning merupakan salah satu teknologi pembelajaran yang relatif baru di Indonesia. Untuk menyederhanakan istilah, maka electronik learning disingkat menjadi e-learning. Menurut Efendi (2005), e-learning merupakan aplikasi internet yang dapat menghubungkan antara pendidik dan peserta didik dalam sebuah ruang belajar online. Jadi tidak harus dalam suatu ruang yang sama dalam proses pembelajaran. Fransisca \& Yunus (2019) mengatakan bahwa dengan adanya e-learning mampu menjadikan solusi untuk pembelajaran yang ekfektif di saat kondisi pandemi covid-19. Menurut Kumar (2002), e-learning sebagai pengajaran dan pembelajaran yang menggunakan rangkaian elektronik (LAN, WAN, atau internet) untuk menyampaikan isi pembelajaran, interaksi atau bimbingan. Darin (2001) berpendapat bahwa elearning merupakan suatu jenis belajar mengajar yang memungkinkan tersampaikannya bahan ajar ke siswa dengan menggunakan media internet, intranet atau media jaringan komputer lain. Zhang, Zhou, \& Briggs (2006) menyatakan bahwa elearning adalah sistem dalam suatu pembelajaran dengan rangkaian elektronik untuk memudahkan 
peserta didik dalam proses belajar dengan waktu dan tempat secara fleksibel. Karwati (2014) memberikan penjelasan mengenai manfaat dari adanya e-learning yang dapat dilihat dari 2 sudut, yaitu: 1) siswa, dengan adanya e-learning ini memudahkan siswa untuk lebih fleksibel dalam proses belajar; 2) guru, mudah mengontrol dan mengawasi siswa dalam proses belajar utamanya dalam hal penugasan. Hasil penelitian Hikmatiar, Sulisworo, \& Wahyuni (2020) juga menunjukkan bahwa penggunaan e-learning sebagai media pembelajaran mampu memberikan dampak yang baik terhadap hasil belajar siswa. Oleh karena itu dengan adanya pembelajaran e-learning ini diharapkan mampu meningkatkan efektivitas dalam proses pembelajaran yang dilakukan dimanapun dan kapanpun.

Sehingga dari beberapa pendapat di atas, e-learning dikaitkan dengan pembelajaran yang berhubungan dengan suatu pembelajaran berbasis dengan internet. Dapat disimpulkan bahwa elearning merupakan proses pembelajaran dengan menggunakan media internet atau media jaringan komputer serta peralatan elektronik dalam membantu serta memudahkan proses belajar antara guru dan siswa yang dapat dilakukan dimanapun dan kapanpun.

\section{Efektivitas Pembelajaran}

Efektivitas pembelajaran merupakan suatu pengukuran keberhasilan peserta didik dalam proses interaksi dengan peserta didik ataupun pengajar dengan peserta didik yang dapat dilihat pada saat aktivitas proses pembelajaran berlangsung untuk pencapaian tujuan pembelajaran (Rohmawati, 2015). Slameto (2010) menjelaskan bahwa agar dapat meningkatkan pembelajaran yang efektif seorang guru perlu memperhatikan kondisi internal dan eksternal serta strategi belajar. Fathurrahman, dkk (2019) mengatakan bahwa dalam penerapan e-learning diperlukan proses pembelajaran yang efektif. Proses pembelajaran yang efektif dapat dilihat berdasarkan tercapainya tujuan pembelajaran dan juga menghadirkan pengalaman baru sehingga dapat memancing kompetensi siswa. Sehingga proses pembelajaran adalah suatu indikator keberhasilan di bidang pendidikan untuk mewujudkan tercapainya efektifitas pembelajaran (Yohana, Muzakir, \& Dina, 2020). Menurut Nurdin \& Anhusadar (2020), efektivitas pembelajaran dapat dilihat dari pengoptimalan tujuan pembelajaran berdasarkan dengan indikator pencapaian. Jadi diperlukan adanya tolak ukur keberhasilan untuk melihat tercapainya tujuan pembelajaran. Menurut Slavin (2008) terdapat 4 indikator untuk mengukur efektivitas pembelajaran yaitu: 1) kualitas pembelajaran, dapat diukur dari proses dan hasil belajar, proses belajar dapat diketahui dari interaksi antara guru dan siswa dalam proses pembelajaran sedangkan hasil belajar dapat diketahui dari ketuntasan belajar siswa; 2) kesesuaian tingkat pembelajaran, dapat diketahui dari kesiapan siswa dalam mengikuti pembelajaran; 3) insentif, yaitu guru memberikan motivasi kepada siswa dalam mengikuti proses pembelajaran yang sedang berlangsung; 4) waktu, ketepatan waktu siswa dalam mengikuti proses pembelajaran.

Hasil penelitian Chopra, et al (2019) menyatakan bahwa kualitas sistem yang baik dalam pembelajaran e-learning mampu berkontribusi lebih dalam kegiatan belajar mengajar yang sedang berlangsung sehingga efektif diterapkan pada era pandemi covid-19. Hasil penelitian Yohana, Muzakir, \& Dina (2020) juga menjelaskan bahwa pembelajaran menggunakan e-learning yang diterapkan dengan sistem yang baik sangat efektif diterapkan pada program studi Pendidikan Ekonomi. Sehingga agar dapat terciptanya efektivitas pembelajaran yang baik, diperlukan sistem dengan kualitas yang baik agar mampu memberikan hasil yang baik pula. Berdasarkan uraian tersebut dapat disimpulkan bahwa efektivitas pembelajaran merupakan suatu pengukuran keberhasilan untuk melihat tercapainya tujuan pembelajaran melalui sistem dan strategi pembelajaran yang dinilai berdasarkan indikator-indikator menurut Slavin (2008) untuk mengukur efektivitas pembelajaran yaitu: kualitas pembelajaran, kesesuaian tingkat pembelajaran, insentif, dan waktu.

\section{METODE PENELITIAN}

Penelitian ini merupakan penelitian deskriptif dengan pendekatan kualitatif. Penelitian 
deskriptif merupakan metode untuk menghasilkan kesimpulan yang luas untuk dipergunakan sebagai analisis. Penelitian kualitatif adalah metode penelitian yang digunakan untuk meneliti pada kondisi obyek yang alamiah, dimana peneliti adalah sebagai instrumen kunci (Sugiyono, 2019). Teknik pengumpulan data yang digunakan dalam penelitian yaitu wawancara terstandar kepada 5 siswa sebagai subjek penelitian. Alasan pemilihan 5 orang siswa yaitu 5 orang siswa sudah cukup mewakili untuk memperoleh data. Teknik pengambilan informan yang digunakan yaitu random sampling yaitu pengambilan anggota sampel dari populasi yang dilakukan secara acak tanpa memperhatikan strata yang ada dalam populasi itu Sugiyono (2019).

Berdasarkan empat indikator efektivitas pembelajaran menurut Slavin (2008) terdiri dari 8 pertanyaan dari segi kualitas pembelajaran, 7 pertanyaan dari segi kesesuaian tingkat pembelajaran, 7 pertanyaan dari segi insentif, 7 pertanyaan dari segi waktu. Sedangkan angket disebarkan bersamaan pada saat peneliti melakukan wawancara online melalui google form kepada 37 siswa kelas X OTKP 1 di SMKN 2 Buduran Sidoarjo yang terdiri dari 20 butir pernyataan sebagai data pendukung dengan menggunakan skala likert. Alasan pemilihan 37 siswa yaitu peneliti menggunakan batasan penelitian dengan lebih memfokuskan pada kelas X OTKP 1 di SMKN 2 Buduran Sidoarjo. Teknik analisis data angket dengan menggunakan grafik yang terdapat pada google form. Keabsahan data dalam penelitian ini menggunakan triangulasi sumber. Triangulasi sumber dalam penelitian ini adalah 3 orang yang terdiri dari 1 guru mata pelajaran kearsipan dan 2 siswa. Teknik analisis data menggunakan Model Miles dan Huberman yang terdiri dari pengumpulan data, reduksi data, penyajian data, dan penarikan kesimpulan (Sugiyono, 2019) yang langkah-langkahnya dapat dijelaskan sebagai berikut: 1) pengumpulkan data, dilakukan peneliti dengan melakukan wawancara dan angket; 2) reduksi data, data yang dihasilkan dari wawancara dan angket merupakan data mentah yang bersifat kompleks, untuk itu peneliti melakukan pemilihan data yang relevan dan data yang bermakna untuk disajikan dengan cara memilih data pokok atau inti yang memfokuskan pada data tentang efektivitas e-learning sebagai media pembelajaran mata pelajaran kearsipan di SMKN 2 Buduran Sidoarjo pada era pandemi covid-19; 3) penyajian data, menyajikan data dalam bentuk narasi berupa informasi yang berkaitan dengan efektivitas e-learning sebagai media pembelajaran mata pelajaran kearsipan di SMKN 2 Buduran Sidoarjo pada era pandemi covid-19; 4) penarikan kesimpulan, penarikan kesimpulan dengan menggunakan metode induktif. Kesimpulan tersebut kemudian diverifikasi dengan berpedoman pada hasil reduksi data dan penyajian data, sehingga kesimpulan yang diambil tidak menyimpang dari permasalahan penelitian.

\section{HASIL DAN PEMBAHASAN}

Efektivitas E-learning sebagai Media Pembelajaran Mata Pelajaran Kearsipan di SMKN 2 Buduran Sidoarjo pada Era Pandemi Covid-19

Berdasarkan hasil penelitian yang telah dilakukan oleh peneliti melalui wawancara dan angket kepada subjek penelitian dan triangulasi sumber, untuk mengukur efektivitas e-learning sebagai media pembelajaran menggunakan 4 indikator yaitu kualitas pembelajaran, kesesuaian tingkat pembelajaran, insentif, dan waktu (Slavin, 2008). Adapun 4 indikator tersebut dapat dipaparkan sebagai berikut:

1. Efektivitas E-learning sebagai Media Pembelajaran Mata Pelajaran Kearsipan di SMKN 2 Buduran Sidoarjo pada Era Pandemi Covid 19 dari Segi Kualitas Pembelajaran

Berdasarkan hasil wawancara peneliti dengan subjek penelitian dan triangulasi sumber menyatakan bahwa proses pembelajaran selama ada pandemi covid-19 pada mata pelajaran kearsipan di kelas X OTKP 1 di SMKN 2 Buduran Sidoarjo menggunakan 2 aplikasi yaitu google classroom \& whatsapp. Siswa menyukai kedua aplikasi tersebut untuk diterapkan pada pembelajaran kearsipan pada era pandemi covid19 ini dikarenakan lebih mudah digunakan dan tidak ada kendala yang dapat dilihat pada gambar 1 sebagai berikut: 

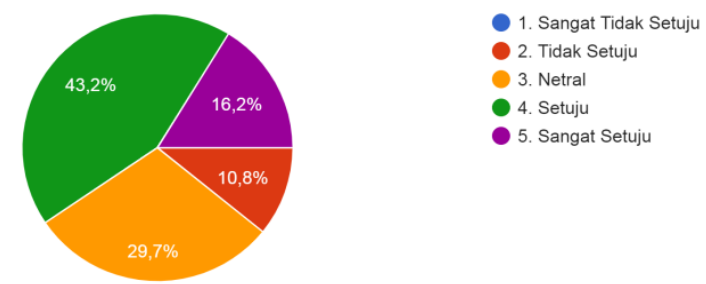

\section{Gambar 1. E-learning dapat Diakses dengan Mudah Sumber: Data Diolah Peneliti (2021)}

Hasil perolehan angket berdasarkan diagram lingkaran pada gambar 1 di atas menunjukkan bahwa persentase e-learning dapat diakses dengan mudah bagi siswa kelas X OTKP 1 di SMKN 2 Buduran Sidoarjo sebesar 16,2\% siswa sangat setuju, $43.2 \%$ siswa setuju, $29,7 \%$ siswa netral, $10.8 \%$ siswa tidak setuju. Sehingga persentase terbanyak sebesar $43.2 \%$ siswa setuju bahwa e-learning dapat diakses dengan mudah menggunakaan google classroom dan whatsapp. Pernyataan tersebut sesuai dengan hasil penelitian Maharani \& Kartini (2019) yang menjelaskan bahwa google classroom mampu meningkatkan minat dan motivasi sebagai media pembelajaran $e$ learning karena fitur-fitur yang digunakan lengkap dan mudah. Hasil penelitian Nur, Pradipta, \& Maliki (2020) mengatakan bahwa pembelajaran dengan e-learning mudah dimengerti dan aplikasi google classroom merupakan aplikasi yang mudah diakses dan dipahami. Penelitian relevan dilakukan oleh Zulkifli, Nurmayanti, \& Ferdiansyah (2021) yang menyatakan bahwa media pembelajaran $e$ learning dengan menggunakan aplikasi yang mudah dalam mengakses pembelajaran sesuai dengan kebutuhan yang diperlukan mampu meningkatkan efektivitas pembelajaran saat pandemi covid-19, oleh karena itu media pembelajaran yang sesuai dapat berdampak signifikan terhadap kualitas pembelajaran. Penelitian Dewantara \& Nurgiansah (2021) menjelaskan bahwa aplikasi whatsapp terbukti efektif digunakan saat pembelajaran di era pandemi covid 19. Lestari, Gunawan, \& Yulianci (2020) dalam penelitiannya juga menyampaikan bahwa aplikasi google classroom dan whatsapp berdampak efektif dalam meningkatkan kualitas pembelajaran selama pandemi covid-19. Penelitian
Bocconcelli \& Tunisini (2001) menyatakan bahwa media pembelajaran $e$-learning merupakan bagian dari proses pembelajaran sehingga siswa dapat berkomunikasi dengan guru secara mudah walaupun pada era pandemi covid-19, oleh karena itu media pembelajaran yang sesuai dapat berdampak signifikan terhadap kualitas pembelajaran. Dalam pelaksanaan e-learning ini diperlukan media pembelajaran yang tepat agar pembelajaran berjalan dengan efektif (Bentley, Selassie, \& Shegunshi, 2012). Sehingga diperlukan aplikasi yang tepat agar dapat mewujudkan kualitas pembelajaran yang efektif pada era pandemi covid-19.

Guru mata pelajaran kearsipan menyatakan bahwa pembelajaran e-learning di SMKN 2 Buduran Sidoarjo sebelum adanya pandemi covid-19 telah menggunakan moodle sebagai media e-learning untuk menunjang pembelajaran, namun moodle tidak lagi digunakan setelah adanya pandemi covid-19 ini karena moodle tidak sesuai apabila diterapkan dalam kegiatan pembelajaran e-learning dimana pada moodle tidak selalu mendukung web browser yang ada sekalipun dapat diperbaharui dengan cara mendownload aplikasi moodle. Karena keterbatasan tersebut guru mata pelajaran kearsipan lebih memilih menggunakan aplikasi google classroom dan whatsapp group. Setelah adanya pandemi covid-19 guru mata pelajaran kearsipan menyatakan bahwa telah menerapkan aplikasi google classroom dan whatsapp sebagai media pembelajaran e-learning. Whatsapp sebagai media komunikasi dan google classroom sebagai media untuk memberikan materi serta penugasan maupun ulangan yang diberikan oleh guru. Hal ini didukung oleh hasil penelitian yang dilakukan 
Hikmatiar, Sulisworo, \& Wahyuni (2020) yang menyampaikan bahwa google classroom layak digunakan sebagai media pembelajaran, dimana pada hasil studi menunjukkan bahwa rata-rata

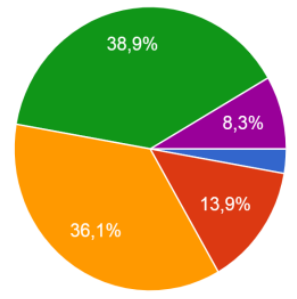

validasi baik sehingga google classroom layak untuk digunakan dalam pembelajaran e-learning. Hal ini juga dapat dilihat pada gambar 2 sebagai berikut:

\section{Gambar 2. E-learning Memberikan Kemudahan dalam Memahami Materi yang Disampaikan Guru Sumber: Data Diolah Peneliti (2021)}

Hasil perolehan angket berdasarkan diagram lingkaran pada gambar 2 di atas menunjukkan bahwa persentase e-learning memberikan kemudahan dalam memahami materi yang disampaikan guru sebesar $8.3 \%$ siswa sangat setuju, $38.9 \%$ siswa setuju, $36.1 \%$ siswa netral, $13.9 \%$ siswa tidak setuju. Sehingga persentase terbanyak sebesar $38.9 \%$ siswa setuju bahwa $e$ learning memberikan kemudahan dalam memahami materi yang disampaikan oleh guru.

Berdasarkan hasil wawancara peneliti dengan siswa mengatakan bahwa guru menyampaikan materi pelajaran kearsipan dengan sangat baik. Adanya kompetensi yang dimiliki oleh pendidik melalui penyampaian materi pelajaran dengan baik diharapkan mampu membimbing peserta didik untuk belajar mandiri melalui berbagai sumber belajar yang diterapkan di dalam proses pembelajaran (Puspasari \& Puspasari, 2019). Pernyataan tersebut relevan dengan hasil penelitian Alvianto (2020) yang menyatakan bahwa penyampaian materi oleh guru saat pembelajaran melalui e-learning dapat dimengerti dengan jelas oleh siswa sehingga menimbulkan interaksi yang baik antara siswa dan guru meskipun penyampaian materi menggunakan aplikasi virtual. Oleh karena itu, dengan adanya $e$ learning ini membantu guru dalam menyampaikan materi dengan baik. Hasil penelitian Darsono, dkk (2020) menjelaskan bahwa siswa merasa bahwa dengan pembelajaran e-learning mampu memberikan kemudahan dalam memahami materi serta meningkatkan kompetensi siswa karena materi yang dipelajari siswa selama pembelajaran e-learning dapat dipahami dengan baik.

Namun materi pelajaran kearsipan tidak sesuai dengan materi yang ada di Rancangan Pelaksanaan Pembelajaran (RPP) maupun silabus. Hal itu juga dibenarkan oleh guru yang mengatakan bahwa pada saat pandemi covid-19 kurikulum disederhanakan dan tidak harus sesuai dengan Rancangan Pelaksanaan Pembelajaran (RPP), maka dari itu materi yang diajarkan adalah materi yang penting saja. Penelitian yang dilakukan oleh Handarini \& Wulandari (2020) menyampaikan bahwa Rancangan Pelaksanaan Pembelajaran (RPP) atau biasa disebut RPP satu lembar yang mana penilaian bisa dikurangi agar tidak memberatkan siswa saat berlangsungnya proses pembelajaran melalui e-learning untuk disesuaikan dengan materi dan kondisi jika tidak memungkinkan maka diganti dengan tugas yang lain sehingga hal tersebut sesuai untuk diterapkan saat pandemi covid-19 agar tercapainya efektivitas pembelajaran. Khusniyah \& Hakim (2019) dalam penelitiannya menjelaskan bahwa efektivitas pembelajaran e-learning dikatakan efektif apabila materi yang diajarkan secara lebih singkat dan jelas untuk meminimalkan penggunaan paket data, hal ini dapat meningkatkan efektivitas pembelajaran namun tidak bisa diterapkan sepenuhnya dikarenakan guru juga harus melihat kondisi materi yang akan diajarkan. Untuk penugasan, guru memberikan tugas melalui google classroom 
dengan deadline yang telah ditentukan. Hal itu didukung dengan hasil wawancara peneliti dengan guru yang menjelaskan bahwa penugasan melalui e-learning berupa tugas yang diunggah pada google classroom dengan deadline tugas berdasarkan kesulitan materi dalam penugasan, jika materi dirasa lebih susah maka guru memberikan waktu hingga pukul 15.00 WIB sebagai deadline penugasan. Hasil penelitian Hartati (2020) menyatakan bahwa seorang pendidik menentukan deadline saat pemberian tugas mampu meningkatkan kualitas pembelajaran dikarenakan seorang peserta didik akan merasa terpacu dalam mengerjakan tugas yang diberikan pendidik dengan tepat waktu. Hasil penelitian Mandasari, Rahmadhani, \& Wahyuni (2020) dalam penelitiannya mengatakan bahwa dengan memberikan penambahan waktu dalam mengerjakan tugas akan memberikan dampak positif terhadap hasil belajar siswa sehingga hal tersebut dapat mencapai kualitas pembelajaran yang baik. Penelitian tersebut juga relevan dengan hasil penelitian Ibrahim \& Suardiman (2014) yang menyatakan bahwa seorang peserta didik yang mampu dalam mengerjakan tugas sesuai deadline yang telah ditentukan akan berpengaruh terhadap kualitas pembelajaran.

Ketika mengikuti pembelajaran melalui $e$ learning siswa memiliki kendala pada paket data. Siswa mengatakan bahwa paket data merupakan salah satu faktor kendala saat mengikuti pelajaran, namun hal tersebut berangsur dapat teratasi dengan adanya bantuan kuota internet dari Kemendikbud. Hasil penelitian Zuraini \& Nurhayati (2021) menjelaskan bahwa adanya bantuan paket data dari Kemendikbud sebesar 10 GB per siswa akan memudahkan dan membantu siswa dalam mengakses e-learning. Hasil penelitian Nguyen (2015) menyatakan bahwa paket data sangat dibutuhkan dalam pembelajaran e-learning, karena karakteristik pembelajaran ini selalu membutuhkan jaringan internet. Abidin, Hudaya, \& Anjani (2020) dalam penelitiannya menyampaikan bahwa proses pembelajaran e-learning dikatakan cukup efektif karena telah mampu mengatasi hambatan terutama bantuan paket data yang diterima oleh siswa. Sianturi (2018) dalam hasil penelitiannya juga menyatakan bahwa dengan adanya internet yang digunakan siswa secara signifikan dapat mempengaruhi motivasi siswa dalam pembelajaran e-learning.

Berdasarkan data yang diperoleh oleh peneliti, nilai Kriteria Ketuntasan Minimal (KKM) mata pelajaran kearsipan SMK Negeri 2 Buduran Sidoarjo adalah 80. Diketahui pada nilai UTS mata pelajaran kearsipan maka jumlah siswa yang memenuhi standar nilai Kriteria Ketuntasan Minimal (KKM) berjumlah 20 siswa $(72,6 \%)$, sedangkan 16 siswa $(27,4 \%)$ belum memenuhi standar KKM. Suryosubroto (2009) menjelaskan bahwa belajar dikatakan tuntas dan efektif apabila lebih dari $70 \%$ mendapatkan nilai lebih dari 80 , yang berarti siswa yang memiliki kualitas belajar yang baik yaitu $\geq$ KKM. Hal ini didukung hasil penelitian Mimi (2020) yang menjelaskan bahwa dengan adanya kualitas pembelajaran yang baik tentunya hal ini akan berdampak terhadap efektivitas pada proses pembelajaran. Penelitian yang dilakukan oleh Dewi, Rosalina, \& Ernawati (2021) juga menyatakan bahwa dengan kualitas pembelajaran e-learning yang baik mampu mencapai hasil belajar siswa sehingga pembelajaran dapat dikatakan efektif. Sehingga efektivitas pembelajaran e-learning sebagai media pembelajaran pada mata pelajaran kearsipan dari segi kualitas pembelajaran dapat dikatakan efektif.

\section{Efektivitas E-learning sebagai Media Pembelajaran Mata Pelajaran Kearsipan di SMKN 2 Buduran Sidoarjo pada Era Pandemi Covid-19 dari segi Kesesuaian Tingkat Pembelajaran}

Berdasarkan hasil wawancara peneliti dengan subjek penelitian dan triangulasi sumber menyatakan bahwa guru dan siswa memiliki sarana berupa laptop dan hp sendiri di rumah untuk melakukan pembelajaran melalui e-learning yang dapat dilihat pada gambar 3 sebagai berikut: 

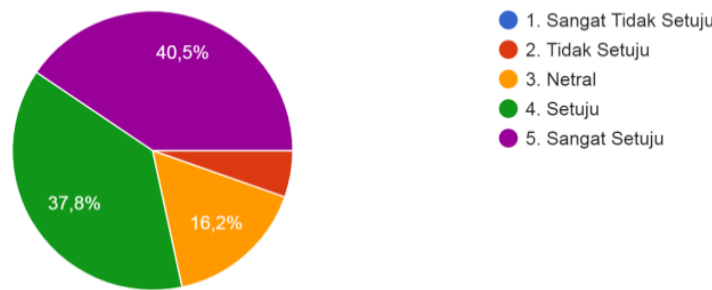

\section{Gambar 3. Siswa Memiliki Laptop dan HP untuk Melakukan Kegiatan Pembelajaran melalui E-learning Sumber: Data Diolah Peneliti (2021)}

Perolehan angket berdasarkan diagram lingkaran pada gambar 3 di atas menunjukkan bahwa persentase siswa memiliki laptop dan $\mathrm{hp}$ untuk melakukan kegiatan pembelajaran melalui $e$ learning sebesar $40.5 \%$ siswa sangat setuju, $37.8 \%$ siswa setuju, $16.2 \%$ siswa netral. Sehingga persentase terbanyak sebesar $40.5 \%$ siswa sangat setuju bahwa dalam melakukan kegiatan pembelajaran e-learning siswa memiliki laptop dan hp.

Siswa menyampaikan bahwa untuk koneksi internet biasanya mendapat bantuan kuota dari Kemendikbud, namun beberapa siswa juga menggunakan wifi dalam melakukan kegiatan pembelajaran melalui $e$-learning yang dapat dilihat pada gambar 4 sebagai berikut:
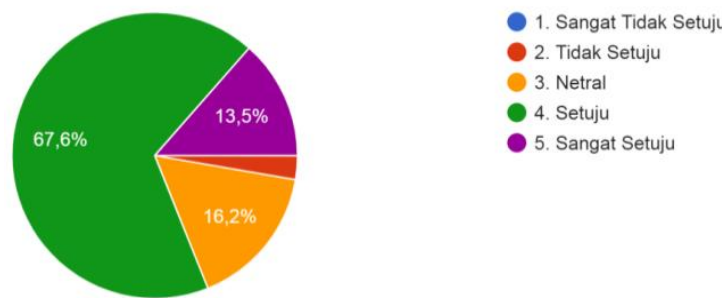

\section{Gambar 4. Koneksi Internet Siswa Menggunakan Wifi Maupun Kuota Internet dalam Melakukan Kegiatan Pembelajaran melalui E-learning Sumber: Data Diolah Peneliti (2021)}

Hasil perolehan angket berdasarkan diagram lingkaran pada gambar 4 di atas menunjukkan bahwa koneksi internet siswa menggunakan wifi maupun kuota internet dalam melakukan kegiatan pembelajaran melalui $e$ learning sebesar $13.5 \%$ siswa sangat setuju, $67.6 \%$ siswa setuju, $16.2 \%$ siswa netral. Sehingga persentase terbanyak sebesar $67.6 \%$ siswa setuju bahwa koneksi internet siswa menggunakan wifi maupun kuota internet dalam melakukan kegiatan pembelajaran melalui e-learning. Hal ini sesuai dengan hasil penelitian Rustiani, et al (2019) menyatakan bahwa pada saat pembelajaran melalui e-learning berlangsung siswa membutuhkan sarana dan prasarana yang dapat mendukung berlangsungnya pembelajaran agar berjalan dengan lancar. Setelah sarana dan prasarana telah dipersiapkan kemudian sebelum pembelajaran dimulai, siswa membaca materi yang diberikan oleh guru berupa power point di whatsapp group terlebih dahulu agar proses pembelajaran $e$ learning pada mata pelajaran kearsipan berjalan dengan kondusif. Penelitian Chandrawati (2010) mengatakan bahwa guru diharapkan mampu memberikan materi, menjelaskan dan mengarahkan siswa. Sehingga apabila ditemukan suatu kesulitan dapat ditanyakan kepada guru saat proses pembelajaran, dengan demikian siswa dapat lebih siap dan semangat untuk mengikuti pembelajaran melalui e-learning. Penelitian Cindrakasih (2020) menjelaskan bahwa saat pembelajaran e-learning, guru tetap memberikan materi berupa power point sebelum siswa diberikan penugasan agar siswa mampu 
memahami materi baru yang diberikan guru. Penelitian Mustakim (2020) juga menyampaikan bahwa untuk melihat kesiapan siswa dalam proses pembelajaran diantaranya melalui respon siswa terhadap materi yang diberikan oleh guru. Hal ini dapat dilihat pada gambar 5 sebagai berikut:
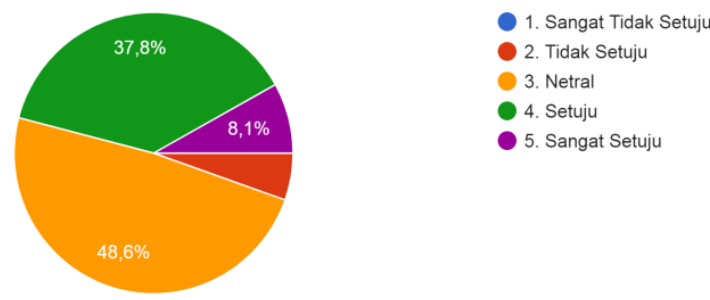

\section{Gambar 5. Guru Selalu Memberikan Pertanyaan Sebelum Menyampaikan Materi Pelajaran di E-learning Sumber: Data Diolah Peneliti (2021)}

Hasil perolehan angket berdasarkan diagram lingkaran pada gambar 5 di atas menunjukkan bahwa guru selalu memberikan pertanyaan sebelum menyampaikan materi pelajaran di e-learning sebesar $8.1 \%$ siswa sangat setuju, $37.8 \%$ siswa setuju, $48.6 \%$ siswa netral. Sehingga persentase terbanyak sebesar $8.1 \%$ siswa sangat setuju bahwa guru selalu memberikan pertanyaan sebelum menyampaikan materi pelajaran di e-learning.

Siswa menyatakan terkait dengan pre-test dan juga pertanyaan sebelum memulai materi guru tidak pernah memberikan pre-test mapun pertanyaan sebelum kegiatan pembelajaran dimulai melalui e-learning. Namun berdasarkan wawancara peneliti kepada guru mengatakan bahwa memilih untuk memantau, mengingatkan serta menjawab respon beberapa pertanyaan siswa akan memacu siswa untuk aktif merespon dan bertanya di whatsapp group ataupun whatsapp pribadi maupun komentar pada google classroom terkait dengan materi yang diberikan oleh guru, dengan demikian diharapkan siswa dapat lebih kondusif dan siap menerima materi saat pembelajaran berlangsung. Hal ini didukung hasil penelitian dari Nengsih, Deswati, \& Hendri, 2020) yang menyatakan bahwa pembelajaran dikatakan efektif apabila seorang guru memastikan keaktifan peserta didik dalam kesiapan untuk mengikuti pembelajaran e-learning secara kondusif. Hal tersebut juga relevan dengan pendapat Slavin (2008) yang mengatakan bahwa keefektivan pembelajaran dapat diukur dari segi kesesuaian tingkat pembelajaran yaitu dapat dilihat dari kesiapan siswa serta keaktifan siswa dalam mengikuti pembelajaran. Sehingga efektivitas pembelajaran e-learning sebagai media pembelajaran pada mata pelajaran kearsipan dari segi kesesuaian tingkat pembelajaran dapat dikatakan efektif karena guru telah memastikan kesiapan siswa untuk mengikuti pembelajaran sehingga mampu menumbuhkan keaktifan siswa dalam kegiatan pembelajaran.

\section{Efektivitas E-learning sebagai Media Pembelajaran Mata Pelajaran Kearsipan di SMKN 2 Buduran Sidoarjo pada Era Pandemi Covid-19 dari Segi Insentif}

Berdasarkan hasil wawancara peneliti dengan subjek penelitian dan triangulasi sumber menyatakan bahwa saat pembelajaran berlangsung guru memberikan motivasi kepada siswa dengan cara memberikan nasihat-nasihat dan kata-kata agar semakin rajin belajar dalam menggapai citacita. Slavin (2008) berpendapat bahwa keefektivan pembelajaran dapat diukur dari segi insentif yaitu cara seorang pendidik memberikan motivasi kepada peserta didik dapat dilihat dari respon dan minat peserta didik dalam mengikuti pembelajaran yang dapat dilihat pada gambar 6 sebagai berikut: 


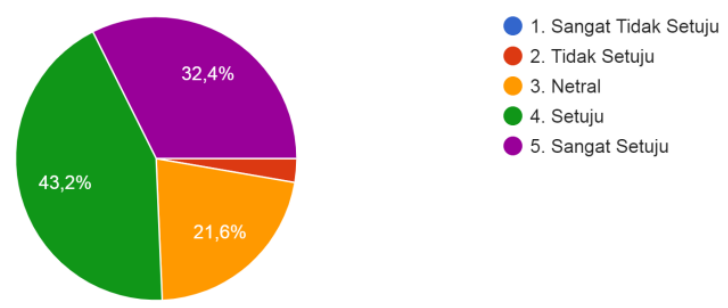

\section{Gambar 6. Guru Telah Memberikan Motivasi kepada Siswa Sebelum Mengikuti Pembelajaran E-learning Sumber: Data Diolah Peneliti (2021)}

Hasil perolehan angket berdasarkan diagram lingkaran pada gambar 6 di atas menunjukkan bahwa guru telah memberikan motivasi kepada siswa sebelum mengikuti pembelajaran e-learning sebesar $32.4 \%$ siswa sangat setuju, $43.2 \%$ siswa setuju, $21.6 \%$ siswa netral. Sehingga persentase terbanyak sebesar $43.2 \%$ siswa setuju bahwa guru telah memberikan motivasi kepada siswa sebelum mengikuti pembelajaran e-learning.
Siswa menyampaikan bahwa guru memberikan nilai tambahan kepada siswa yang aktif mengumpulkan tugas lebih awal sehingga dapat memotivasi siswa untuk segera menyelesaikan tugas. Guru juga mengatakan bahwa memberikan nilai tambahan kepada siswa yang aktif bertanya kepada guru saat pembelajaran e-learning untuk memotivasi siswa agar semangat dalam belajar yang dapat dilihat pada gambar 7 sebagai berikut:
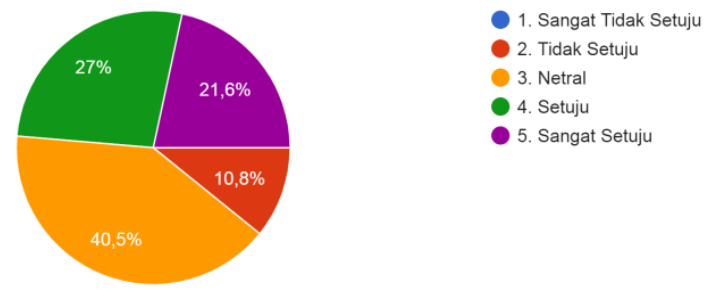

\section{Gambar 7. Guru Memberikan Hadiah kepada Siswa yang Aktif Bertanya kepada Guru Saat Pembelajaran melalui E-learning Sumber: Data Diolah Peneliti (2021)}

Hasil perolehan angket berdasarkan diagram lingkaran pada gambar 7 di atas menunjukkan bahwa guru memberikan hadiah kepada siswa yang aktif bertanya kepada guru saat pembelajaran melalui e-learning sebesar $21.6 \%$ siswa sangat setuju, $27 \%$ siswa setuju, $40.5 \%$ siswa netral, $10.8 \%$ siswa tidak setuju. Sehingga persentase terbanyak sebesar $40.5 \%$ siswa memilih netral dikarenakan guru mengatakan bahwa tidak memberikan hadiah dalam bentuk barang akan tetapi berupa penambahan nilai kepada siswa yang mampu bertanya dan aktif di whatsapp group maupun google classroom sebagai upaya untuk memotivasi siswa agar lebih semangat dalam belajar melalui e-learning.
Guru mengungkapkan bahwa dengan memberikan hadiah berupa penambahan nilai kepada siswa yang mampu menjawab pertanyaan dari guru dengan benar saat pembelajaran $e$ learning berlangsung dapat memotivasi siswa untuk lebih semangat dalam belajar. Hal tersebut juga dibenarkan oleh siswa yang mengatakan bahwa dengan memberikan tambahan nilai saat guru memberikan pertanyaan, siswa merasa termotivasi untuk menjawab pertanyaan dari guru dengan benar. Hal ini didukung oleh penelitian Slameto (2010) yang menyatakan bahwa memberikan penambahan nilai kepada siswa dapat membangkitkan motivasi siswa untuk belajar lebih giat. Sehingga dengan memberikan motivasi yang 
positif kepada siswa akan berdampak baik terhadap proses pembelajaran melalui e-learning selama pandemi covid-19. Guru juga menyampaikan bahwa memberikan nilai tambahan kepada 10 siswa yang mengumpulkan tugas tepat waktu yang dapat dilihat pada tabel 8 sebagai berikut:

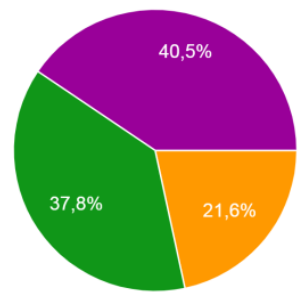

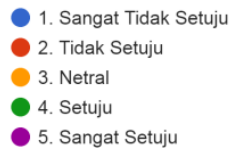

\section{Gambar 8. Guru Memberikan Tambahan Nilai kepada Siswa yang dapat Menyelesaikan Tugas Tepat Waktu Saat Pembelajaran melalui E-learning Sumber: Data Diolah Peneliti (2021)}

Hasil perolehan angket berdasarkan diagram lingkaran pada gambar 8 di atas menunjukkan bahwa guru memberikan tambahan nilai kepada siswa yang dapat menyelesaikan tugas tepat waktu saat pembelajaran melalui e-learning sebesar $40.5 \%$ siswa sangat setuju, $37.8 \%$ siswa setuju, $21.6 \%$ siswa netral. Sehingga persentase terbanyak sebesar $40.5 \%$ siswa sangat setuju bahwa guru memberikan tambahan nilai kepada siswa yang dapat menyelesaikan tugas tepat waktu saat pembelajaran melalui $e$-learning. Hal tersebut didukung hasil penelitian dari Widiyono (2020) yang menyatakan bahwa pemberian nilai tambahan kepada peserta didik yang mengerjakan tugas tepat waktu mampu memberikan motivasi belajar siswa yang dapat berpengaruh terhadap keaktifan siswa dalam pembelajaran. Kemudian siswa mengatakan bahwa guru sering memberikan pujian kepada siswa yang telah berani untuk bertanya maupun menjawab. Hal ini diperkuat oleh guru yang mengatakan bahwa dengan memberikan pujian kepada siswa dapat memberikan energi positif kepada siswa sehingga siswa menjadi lebih aktif dalam pembelajaran. Hal ini didukung oleh penelitian Solikha (2018) yang meyampaikan bahwa tingkat keefektivan pembelajaran ditandai dengan keaktifan siswa. Oleh karena itu semakin aktif siswa dalam pembelajaran maka semakin efektif pula proses pembelajaran berlangsung.

Guru mengajak siswa berkomunikasi menggunakan whatsapp group untuk memberikan kemudahan dalam berinteraksi antar siswa maupun dengan guru. Oleh karena itu, apabila siswa mengalami kesulitan mengenai materi kearsipan diperbolehkan untuk bertanya melalui whatsapp pribadi dengan guru, dimana hal ini dapat ditunjukkan pada gambar 9 sebagai berikut:
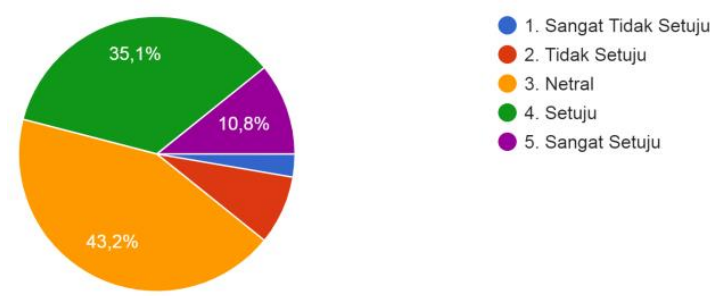

Gambar 9. Pembelajaran melalui E-learning Memberikan Kemudahan dalam Berinteraksi dan Berkomunikasi dengan Guru Sumber: Data Diolah Peneliti (2021) 
Hasil perolehan angket berdasarkan diagram lingkaran pada gambar 9 di atas menunjukkan bahwa pembelajaran melalui $e$ learning memberikan kemudahan dalam berinteraksi dan berkomunikasi dengan guru sebesar $10.8 \%$ siswa sangat setuju, $35.1 \%$ siswa setuju, $43.2 \%$ siswa netral. Sehingga persentase terbanyak sebesar $43.2 \%$ siswa memilih netral dikarenakan siswa mengatakan bahwa beberapa teman terkadang kebingungan ketika mendapatkan tugas secara kelompok yang diberikan oleh guru yang diakibatkan kurangnya komunikasi antar siswa. Hasil penelitian dari Bocconcelli \& Tunisini (2001) menjelaskan bahwa komunikasi yang baik dapat berdampak signifikan terhadap proses pembelajaran. Dalam pelaksanaan e-learning ini diperlukan model komunikasi yang tepat agar pembelajaran berjalan dengan efektif (Bentley, Selassie, \& Shegunshi, 2012). Penelitian Badrudin, Ginanjar, \& Wartono (2020) mengatakan bahwa untuk dapat mewujudkan efektifitas pembelajaran selain diperlukan komunikasi yang baik antara guru dan siswa juga diharapkan mampu berkomunikasi yang baik antara guru dan wali murid. Oleh karena itu komunikasi merupakan hal yang sangat berpengaruh atas berjalannya suatu proses pembelajaran. Solihin, Muin, \& Iqbal (2021) juga menyatakan bahwa komunikasi antara guru dan siswa sangat menentukan keberhasilan proses pembelajaran sehingga diperlukan media yang tepat meskipun pembelajaran dilakukan secara $e$-learning komunikasi yang baik harus tetap dipertahankan agar kegiatan pembelajaran dapat berjalan dengan efektif.

Hasil wawancara peneliti dengan guru mengatakan bahwa untuk membiasakan kebiasaan yang baik sebelum belajar dengan siswa diperlukan adanya komunikasi yang baik antara guru dan siswa, sehingga apabila terdapat materi dan penugasan yang belum dipahami dan mengalami kesulitan, siswa dapat bertanya kepada guru. Guru juga sering memberikan saran agar siswa segera menyelesaikan tugas yang diberikan sehingga tidak sampai menumpuk dengan tugas lainnya. Hal ini didukung dengan hasil penelitian dari Panyajamorn, et al (2018) yang menyatakan bahwa memberikan kebiasaan belajar yang baik pada peserta didik dalam proses pembelajaran $e$ learning akan memberikan dampak yang baik serta dapat memotivasi siswa untuk lebih aktif dalam kegiatan belajar sehingga dapat lebih efektif. Hasil penelitian Firman \& Rahayu (2020) juga mengatakan bahwa penggunaan e-learning mempunyai fleksibilitas yang mampu mendorong motivasi siswa dalam mengikuti pelajaran melalui e-learning agar siswa lebih aktif sehingga mampu mewujudkan efektivitas dalam pembelajaran. Sehingga efektivitas pembelajaran e-learning sebagai media pembelajaran pada mata pelajaran kearsipan dari segi insentif dapat dikatakan efektif karena usaha guru telah memberikan motivasi yang baik pada siswa sehingga siswa dapat lebih aktif untuk mengikuti pembelajaran melalui e-learning.

\section{Efektivitas E-learning sebagai Media Pembelajaran Mata Pelajaran Kearsipan di SMKN 2 Buduran Sidoarjo pada Era Pandemi covid-19 dari Segi Waktu}

Berdasarkan hasil wawancara peneliti dengan subjek penelitian dan triangulasi sumber menyatakan bahwa pada saat pembelajaran dimulai guru memberikan waktu kepada siswa untuk memahami dan membaca materi berupa power point yang diberikan guru, apabila ditemukan kesulitan siswa dapat menanyakan kepada guru melalui whatsapp. Menurut Suryosubroto (2009), aktivitas yang dilakukan siswa berdasarkan penggunaan waktu mencakup persiapan belajar, menerima materi, dan kemampuan diri. Pernyataan ini dapat dilihat pada gambar 10 sebagai berikut: 

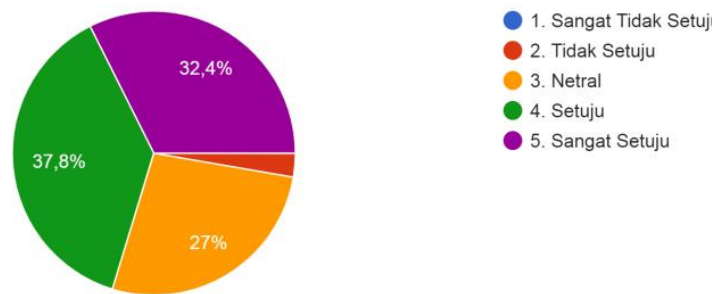

\section{Gambar 10. Guru Memberikan Waktu untuk Mempelajari Materi Terlebih Dahulu Sebelum Pelajaran Kearsipan melalui E-learning Dimulai Sumber: Data Diolah Peneliti (2021)}

Hasil perolehan angket berdasarkan diagram lingkaran pada gambar $10 \mathrm{di}$ atas menunjukkan bahwa guru memberikan waktu untuk mempelajari materi terlebih dahulu sebelum pelajaran kearsipan melalui e-learning dimulai sebesar $32.4 \%$ siswa sangat setuju, $37.8 \%$ siswa setuju, $27 \%$ siswa netral. Sehingga persentase terbanyak sebesar $37.8 \%$ siswa memilih setuju bahwa guru memberikan waktu untuk mempelajari materi terlebih dahulu sebelum pelajaran kearsipan melalui e-learning dimulai. Hal ini membantu siswa dapat memahami materi terlebih dahulu

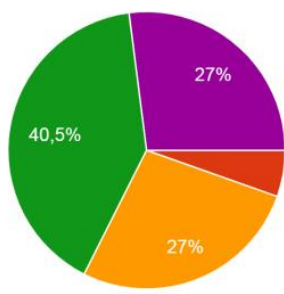

\section{Gambar 11. Guru Memberikan Deadline dalam Pengumpulan \\ Tugas kepada Siswa melalui E-learning Sumber: Data Diolah Peneliti (2021)}

Hasil perolehan angket berdasarkan diagram lingkaran pada gambar $11 \mathrm{di}$ atas menunjukkan bahwa guru memberikan deadline dalam pengumpulan tugas kepada siswa melalui $e$ learning sebesar $27 \%$ siswa sangat setuju, $40.5 \%$ siswa setuju, 27\% siswa netral. Sehingga persentase terbanyak sebesar $40.5 \%$ siswa memilih setuju bahwa guru memberikan deadline dalam pengumpulan tugas kepada siswa melalui $e$ learning. Hasil penelitian Puspitasari, dkk (2018) menyatakan bahwa guru memberikan deadline pada tugas dapat memunculkan motivasi siswa untuk mengumpulkan tugas tepat waktu. Begitu sebelum materi tersebut disampaikan oleh guru dan siswa memiliki bahan materi sebelum pembelajaran dimulai.

Guru mengatakan bahwa agar pembelajaran melalui e-learning tetap kondusif yaitu dengan guru memberikan tugas sesuai deadline yang sudah ditentukan dan juga memulai pembelajaran tempat waktu. Hal tersebut dilakukan agar siswa lebih disiplin serta kondusif dalam melaksanakan pembelajaran melalui $e$ learning, dimana hal ini dapat ditunjukkan pada gambar 11 sebagai berikut:

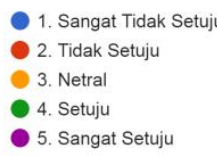

pula dengan hasil penelitian Ibrahim \& Suardiman (2014) mengatakan bahwa dalam pemberian tugas dengan deadline memberikan pengaruh baik terhadap waktu yang dibutuhkan agar dapat lebih efektif, sehingga dengan pemberian deadline penugasan siswa mampu menggunakan waktu dengan sebaik-baiknya.

Guru menyatakan bahwa untuk waktu penyelesaian tugas yang diberikan kepada siswa tergantung pada jenis tugas yang diberikan. Siswa juga berusaha agar tugas yang diberikan tersebut dapat diselesaikan dengan tepat waktu. Slavin (2008) menyampaikan bahwa pembelajaran 
dikatakan efektif apabila siswa dapat menyelesaikan pembelajaran sesuai dengan waktu yang ditentukan. Wawancara yang dilakukan peneliti dengan guru menyampaikan bahwa memulai pelajaran kearsipan dengan tepat waktu yaitu pukul 11.00-12.00 WIB, sehingga dapat mengajarkan kebiasaan belajar yang baik untuk siswa. Hasil penelitian Ichsan, dkk (2020) mengatakan bahwa waktu yang efektif untuk pembelajaran e-learning adalah 2-3 jam. Penelitian Yulianto \& Nugraheni (2021) juga menjelaskan bahwa dengan menggunakan waktu pembelajaran yang telah terjadwal membuat jadwal belajar siswa akan menjadi teratur serta terstruktur. Pernyataan ini dapat ditunjukkan pada gambar 12 sebagai berikut:
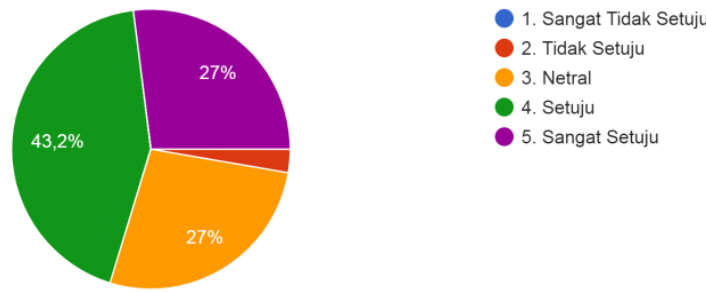

Gambar 12. Pembelajaran melalui E-learning Dimulai Tepat

Waktu dan Sesuai dengan Jadwal Pelajaran Sumber: Data Diolah Peneliti (2021)

Hasil perolehan angket berdasarkan diagram lingkaran pada gambar 12 di atas menunjukkan bahwa pembelajaran melalui $e$ learning dimulai tepat waktu dan sesuai dengan jadwal pelajaran sebesar $27 \%$ siswa sangat setuju, $43.2 \%$ siswa setuju, $27 \%$ siswa netral. Sehingga persentase terbanyak sebesar $43.2 \%$ siswa memilih setuju bahwa pembelajaran melalui e-learning dimulai tepat waktu dan sesuai dengan jadwal pelajaran.

Wawancara yang dilakukan peneliti dengan guru mengatakan bahwa sebelum

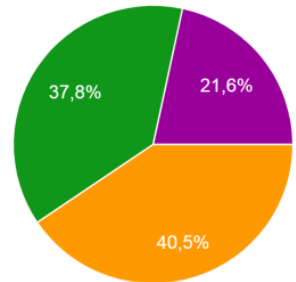

\section{Gambar 13. Guru Memberikan Waktu untuk Siswa Bertanya Setelah Materi Disampaikan melalui E-learning Sumber: Data Diolah Peneliti (2021)}

Hasil perolehan angket berdasarkan diagram lingkaran pada gambar 13 di atas menunjukkan bahwa guru memberikan waktu pembelajaran diakhiri guru selalu memberikan kesempatan kepada siswa untuk bertanya melalui whatsapp group maupun pesan pribadi kepada guru untuk siswa yang merasa belum paham mengenai materi maupun tugas yang telah diberikan. Hasil penelitian Nadziroh (2017) menjelaskan bahwa e-learning mampu meningkatkan efektivitas pembelajaran karena dalam proses belajar tidak tergantung oleh ruang dan waktu sehingga siswa dapat bertanya dengan guru kapanpun dan di manapun. Pernyataan ini dapat ditunjukkan pada gambar 13 sebagai berikut:

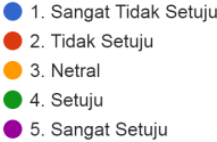

untuk siswa bertanya setelah materi disampaikan melalui e-learning sebesar $21.6 \%$ siswa sangat setuju, $37.8 \%$ siswa setuju, $40.5 \%$ siswa netral. 
Sehingga persentase terbanyak sebesar $40.5 \%$ siswa memilih netral dikarenakan guru jarang memberikan waktu untuk bertanya setelah materi disampaikan. Hasil penelitian Ravitz \& Blazevski (2014) mengatakan bahwa sebelum mengakhiri pembelajaran guru memberikan waktu kepada siswa untuk bertanya agar siswa lebih aktif sehingga mampu meningkatkan efektivitas pembelajaran melalui e-learning. Hasil penelitian Adhikari, et al (2018) yang menyatakan bahwa penggunaan waktu dengan baik dalam proses pembelajaran dapat meningkatkan efektivitas pembelajaran. Hasil penelitian Hartanto (2016) menjelaskan bahwa penggunaan e-learning yang baik adalah dengan membawa materi pelajaran kemana saja tanpa adanya ruang dan waktu yang sebelumnya telah membatasi dunia pendidikan di Indonesia. Ilmadi, et al (2020) dalam hasil penelitiannya menyampaikan bahwa proses pembelajaran melalui e-learning memiliki kelebihan akan fleksibilitas waktu dan tempat serta mendorong siswa untuk lebih mandiri. Penelitian Syarifudin (2020) menjelaskan pula bahwa pembelajaran e-learning semakin membuat siswa untuk lebih mandiri karena siswa akan dituntut untuk fokus dengan alat komunikasi secara individu untuk digunakan sebagai pengumpulan tugas maupun diskusi dan juga menerima materi dari guru, oleh karena itu siswa harus bisa memperhitungkan waktu dengan sebaik-baiknya. Sehingga e-learning sebagai media pembelajaran mata pelajaran kearsipan dari segi waktu dikatakan efektif karena siswa dapat menggunakan waktu yang diberikan oleh guru dengan baik.

\section{SIMPULAN DAN REKOMENDASI}

Berdasarkan hasil dan pembahasan dapat disimpulkan bahwa pembelajaran melalui $e$ learning pada mata pelajaran kearsipan kelas $\mathrm{X}$ OTKP 1 di SMKN 2 Buduran Sidoarjo mendapatkan respon yang baik dari siswa. Pembelajaran melalui e-learning pada mata pelajaran kearsipan sudah berjalan efektif dengan melihat berdasarkan empat indikator efektivitas pembelajaran sebagai berikut: dari segi kualitas pembelajaran, dapat dilihat dari proses dan hasil dalam pembelajaran pada kelas X OTKP 1 di SMKN 2 Buduran Sidoarjo menggunakan 2 aplikasi yaitu google classroom dan whatsapp pada mata pelajaran kearsipan. Siswa merespon dengan baik dikarenakan dalam penerapannya media yang digunakan mudah diakses dan mudah dipahami. Hasil belajar siswa yang mendapatkan nilai lebih dari 80 sebesar $72.6 \%$, sehingga efektivitas pembelajaran e-learning dari segi kualitas pembelajaran terpenuhi dan dapat dikatakan efektif; dari segi kesesuaian tingkat pembelajaran, dapat dilihat dari kesiapan siswa dan guru pada saat akan memulai pelajaran dan berlangsungnya proses pembelajaran pada siswa kelas X OTKP 1 di SMKN 2 Buduran Sidoarjo seperti terpenuhinya sarana dan prasarana yaitu $\mathrm{hp}$ dan laptop, guru memberikan materi untuk dipelajari terlebih dahulu oleh siswa. Sehingga kesesuaian tingkat pembelajaran telah tepat dan dikatakan efektif karena siswa sudah siap untuk mengikuti pembelajaran; dari segi insentif, dapat dilihat dari aktivitas guru dalam memberikan motivasi pada siswa kelas X OTKP 1 di SMKN 2 Buduran Sidoarjo setiap akan memulai pelajaran dan berlangsungnya pembelajaran dengan memberikan nasihat dan energi positif kepada siswa sehingga siswa menjadi lebih aktif dalam pembelajaran. Guru juga memberikan nilai tambahan kepada siswa yang aktif, sehingga siswa merasa termotivasi dalam belajar melalui $e$ learning. Oleh karena itu semakin aktif siswa dalam pembelajaran maka semakin efektif pula proses pembelajaran berlangsung, dengan demikian pembelajaran melalui e-learning dari segi insentif dapat dikatakan efektif; dari segi waktu, dapat dilihat dari kehadiran guru untuk memulai pelajaran kearsipan dengan tepat waktu sehingga dapat mengajarkan kebiasaan belajar yang baik untuk siswa. Guru memberikan tugas sesuai deadline yang sudah ditentukan agar siswa lebih disiplin dalam pembelajaran melalui $e$ learning. Siswa juga berusaha agar tugas yang diberikan tersebut dapat diselesaikan dengan tepat waktu. Sehingga pembelajaran melalui $e$-learning dari segi waktu dikatakan efektif karena siswa kelas X OTKP 1 di SMKN 2 Buduran Sidoarjo dapat menggunakan waktu pembelajaran dengan baik.

Batasan dalam penelitian ini adalah: 1) penelitian ini hanya difokuskan pada siswa kelas 
X OTKP 1 di SMKN 2 Buduran Sidoarjo; 2) penelitian ini hanya difokuskan pada mata pelajaran kearsipan. Adapun saran dalam penelitian ini adalah diharapkan guru dapat mencoba menambah aplikasi tambahan untuk berlangsungnya pembelajaran kearsipan yaitu aplikasi zoom meeting, karena dengan menggunakan aplikasi tersebut komunikasi secara lisan antara guru dan siswa dapat dilakukan dengan lebih mudah. Demi tercapainya kesempurnaan dari artikel ini, saran peneliti bagi peneliti lain yaitu untuk dapat mengkaji lebih dalam terkait pembelajaran melalui e-learning pada era pandemi covid-19 dengan menggunakan metode lain, seperti metode eksperimen.

\section{DAFTAR PUSTAKA}

Abidin, Z., Hudaya, A., \& Anjani, D. (2020). Efektivitas Pembelajaran Jarak Jauh pada Masa Pandemi Covid-19. Research and Development Journal of Education, 1(1), 131 -

146. http://dx.doi.org/10.30998/rdje.v1i1. $\underline{7659}$.

Adhikari, P., et al. (2020). Effectiveness of Elearning During the Covid-19 Pandemic among the Undergraduate Medical Students in Nepal: an Online Survey. Journal of Pharmacy Practice and Community Medicine, 6(3), 40-43. https://www.jppcm.org/article/2020/6/3/4 $\underline{0-43}$.

Alvianto, A. (2020). Efektivitas Pembelajaran Daring pada Mata Kuliah Pendidikan Agama Islam dalam Situasi Pandemi Covid-19. Ta'dibuna: Jurnal Pendidikan Agama Islam, 3(2), 13-26. http://dx.doi.org/10.30659/jpai.3.2.13-26.

Arisendy, R. \& Puspasari, D. (2021). Analisis Penggunaan Model Pembelajaran Numbered Heads Together (NHT) di SMK Krian 2 Sidoarjo. Jurnal Pendidikan Administrasi Perkantoran, 9(1), 211-223. https://journal.unesa.ac.id/index.php/jpap/ article/view/9614.

Badrudin, A. R., Ginanjar, M. H., \& Wartono, W. (2020). The Effectiveness of Online Based Learning During the Covid-19 Pandemic at Private School in Bogor. Edukasi Islami: Jurnal Pendidikan Islam,9(02), 480-494.

http://dx.doi.org/10.30868/ei.v9i02.909.

Bentley, Y., Selassie, H., \& Shegunshi, A. (2012).

Design and Evaluation of Student-Focused

Elearning. Electronic Journal of ELearning, 10(1), 1-12. https://eric.ed.gov/?id=EJ969431.

Bocconcelli, R. \& Tunisini, A. (2001). La Costellazione Del Mobile Nel Pesarese. Un'analisi Interpretativa. Journal Piccola Impresa, $\quad 4(2), \quad 83-112$. https://publicatt.unicatt.it/handle/10807/1 4063\#.YD4t_28za00.

Chandrawati, S. R. (2010). Pemanfaatan Elearning dalam Pembelajaran. Jurnal Cakrawala Pendidikan, 8(2), 172-181. https://jurnal.untan.ac.id/index.php/jckrw/ article/view/183.

Chien, T. (2012). Computer Self Efficacy and Factors Influencing E-learning Effectiveness. European Journal of Training and Development, 36(7), 670686.

https://doi.org/10.1108/030905912112555 39.

Chopra, G., et al. (2019). Effectiveness of Elearning Portal from Students' Perspectchopraive: a Structural Equation Model (SEM) Approach. Journal Interactive Technology and Smart Education, 16(2), 94-116. https://doi.org/10.1108/ITSE-05-20180027.

Cindrakasih, R. (2020). Efektivitas Pembelajaran Daring Menggunakan Media Online Selama Pandemi Covid-19 pada Mata Kuliah PIK dalam Pandangan Mahasiswa. Jurnal Public Relations ( $J$ $P R), 1(1)$, $39-44$. http://jurnal.bsi.ac.id/index.php/jpr/article/ view/165.

Darin, E. H. (2001). Selling E-learning. Amerika: American Society for Training and Development.

Darsono, H., dkk. (2020). Efektivitas Pembelajaran Jarak Jauh Saat Pandemi Covid-19. 
Jurnal PAJAR (Pendidikan dan Pengajaran)

Volume 5 Nomor 3 April 2021 | ISSN Cetak : 2580 - 8435 | ISSN Online : 2614 - 1337

DOI : http://dx.doi.org/10.33578/pir.v5i4.8403

Prosiding the Industrial Research Workshop and National Seminar, hlm. 1235-1240, Politeknik Negeri Bandung. https://doi.org/10.35313/irwns.v11i1.2190

Dewantara, J. A. \& Nurgiansah, T. H. (2021). Efektivitas Pembelajaran Daring di Masa Pandemi Covid 19 Bagi Mahasiswa Universitas PGRI Yogyakarta. Jurnal Basicedu, 5(1), 367-375. https://doi.org/10.31004/basicedu.v5i1.66 9.

Dewi, M., Rosalina, L., \& Ernawati, E. (2021). The Effectiveness E-learning of Entrepreneurship Courses at State University of Padang during the Covid 19 Pandemic. Indonesian Journal of Informatic Research and Software Engineering (IJIRSE), 1(1), 9-15. https://journal.irpi.or.id/index.php/ijirse/ar ticle/view/39.

Efendi, E. (2005). E-learning Konsep dan Aplikasinya. Yogyakarta: Andi.

Fathurrahman, A., dkk. (2019). Peningkatan Efektivitas Pembelajaran melalui Peningkatan Kompetensi Pedagogik dan Teamwork. Jurnal Manajemen Pendidikan, 7(2), 843-850. https://doi.org/10.33751/jmp.v7i2.1334.

Firman, F. \& Rahayu, S. (2020). Pembelajaran Online di Tengah Pandemi Covid-19. Indonesian Journal of Educational Science (IJES), 2(2), 81-89. https://ojs.unsulbar.ac.id/index.php/ijes/ar ticle/view/659.

Fransisca, M. \& Yunus, Y. (2019). Efektivitas Elearning Tingkat Sekolah Menengah Atas Kota Padang. Indonesian Journal of Computer Science, 8(2), 113-120. https://doi.org/10.33022/ijcs.v8i2.174.

Handarini, O. I. \& Wulandari, S. S. (2020). Pembelajaran Daring sebagai Upaya Study From Home (SFH) Selama Pandemi Covid 19. Jurnal Pendidikan Administrasi Perkantoran (JPAP), 8(3), 496-503. https://journal.unesa.ac.id/index.php/jpap/ article/view/8503.
Hanum, N. S. (2013). Keefetifan E-learning sebagai Media Pembelajaran (Studi Evaluasi Model Pembelajaran E-learning SMK Telkom Sandhy Putra Purwokerto). Jurnal Pendidikan Vokasi, 3(1), 90-102. https://doi.org/10.21831/jpv.v3i1.1584.

Hapsari, T. P. R. N. \& Fitria, A. S. (2020). Efektivitas Pembelajaran Daring Mata Kuliah Evaluasi Pengajaran Bahasa dan Sastra Indonesia Masa Pandemi Covid-19. Jurnal Ilmiah SEMANTIKA, 2(01), 11-20. https://doi.org/10.46772/semantika.v2i01. 259.

Hartanto, W. (2016). Penggunaan E-learning sebagai Media Pembelajaran. Jurnal Pendidikan Ekonomi: Jurnal Ilmiah Ilmu Pendidikan, Ilmu Ekonomi dan Ilmu Sosial, 10(1), 1-18. http://jurnal.unej.ac.id/index.php/JPE/artic le/view/3438.

Hartati, W. (2020). Persepsi Mahasiswa tentang Penerapan E-learning pada Masa Darurat Covid-19. APOTEMA: Jurnal Program Studi Pendidikan Matematika, 6(2), 158159. https://doi.org/10.31597/ja.v6i2.377.

Hikmatiar, H., Sulisworo, D., \& Wahyuni, M. E. (2020). Pemanfaatan Learning Management System Berbasis Google Classroom dalam Pembelajaran. Jurnal Pendidikan Fisika, 8(1), 78-86. https://doi.org/10.26618/jpf.v8i1.3019.

Ibrahim, D. S. \& Suardiman, S. P. (2014). Pengaruh Penggunaan E-learning terhadap Motivasi dan Prestasi Belajar Matematika Siswa SD Negeri Tahunan Yogyakarta. Jurnal Prima Edukasia, 2(1), 66-79. https://doi.org/10.21831/jpe.v2i1.2645.

Ichsan, I. Z., dkk. (2020). Covid-19 dan Elearning: Perubahan Strategi Pembelajaran Sains dan Lingkungan di SMP. JINoP (Jurnal Inovasi Pembelajaran), 6(1), 5061.

https://ejournal.umm.ac.id/index.php/jino p/article/view/11791.

Ilmadi, I., et al. (2020). The Effectiveness of Online Learning for Mathematics Students During the Covid-19 Pandemic. Jurnal Cendekia: Jurnal Pendidikan 
Matematika, 4(2),

1273-1282. https://doi.org/10.31004/cendekia.v4i2.37 2.

Karwati, E. (2014). Pengaruh Pembelajaran Elektronik (E-learning) terhadap Mutu Belajar Mahasiswa. Jurnal Penelitian Komunikasi, $\quad$ 17(1), 41-54. https://core.ac.uk/download/pdf/22963353 9.pdf.

Kemendikbud. (2020). Dampak Covid-19 Bagi Pendidikan.

https://www.kemdikbud.go.id/main/blog/ 2020/03/sikapi-covid19-kemendikbudterbitkan-dua-surat-edaran, diakses pada tanggal 29 Oktober 2020.

Khusniyah, N. \& Hakim, L. (2019). Efektivitas Pembelajaran Berbasis Daring: Sebuah Bukti pada Pembelajaran Bahasa Inggris. Jurnal Tatsqif, 17(1), 19-33. https://doi.org/10.20414/jtq.v17i1.667.

Kumar, J. (2002). Aplikasi E-learning dalam Pengajaran dan Pembelajaran di Sekolah Malaysia. Jakarta: Bahagian Teknologi Pendidikan.

Lestari, P. A. S., Gunawan, G., \& Yulianci, S. (2020). Effectiveness of Online Lectures Using Digital Platform During the Pandemi Covid-19. Indonesian Journal of Applied Science and Technology, 1(3), 107-115. https://journal.publicationcenter.com/index.php/ijast/article/view/59 5.

Lutfiyah, L. \& Sulisawati, D. N. (2019). Efektivitas Pembelajaran Matematika Menggunakan Media Berbasis $E$ learning. Jurnal Pendidikan Matematika; Judika Education, 2(1), 58-65. https://doi.org/10.31539/judika.v2i1.716.

Maharani, N. \& Kartini, K. S. (2019). Penggunaan Google Classroom sebagai Pengembangan Kelas Virtual dalam Keterampilan Pemecahan Masalah Topik Kinematika pada Mahasiswa Jurusan Sistem Komputer. PENDIPA Journal of Science Education, 3(3), 167-173. https://doi.org/10.33369/pendipa.3.3.167173.
Mandasari, L., Rahmadhani, E., \& Wahyuni, S. (2020). Efektivitas Perkuliahan Daring pada Mata Kuliah Analisis Kompleks Selama Pandemi Covid 19. Jurnal AsSalam, 4(2), 269-283. https://jurnalassalam.org/index.php/JAS/article/view/2 05.

Mimi, M. P. S. (2020). Efektivitas Pembelajaran Berbasis Daring pada Mata Kuliah Insya' di Stai Ma'arif Sarolangun. El-Jaudah: Jurnal Pendidikan Bahasa dan Sastra Arab, 1(2), 59-68. http://jurnal.stainmadina.ac.id/index.php/ej/article/view/13 4.

Mustakim, M. (2020). Efektivitas Pembelajaran Daring Menggunakan Media Online Selama Pandemi Covid-19 pada Mata Pelajaran Matematika. Al Asma: Journal of Islamic Education, 2(1), 1-12. http://103.55.216.56/index.php/alasma/art icle/view/13646.

Nadziroh, F. (2017). Analisa Efektifitas Sistem Pembelajaran Berbasis E-learning. Jurnal Ilmu Komputer dan Desain Komunikasi Visual, 2(1), 1-14. https://journal.unusida.ac.id/index.php/jik/ article/view/28.

Nengsih, C. O., Deswati, L., \& Hendri, W. (2020). Efektivitas Pembelajaran E-learning pada Mata Pelajaran Biologi Kelas X IPA SMA di Nagari Punggung Kasik Kecamatan Lubuk Alung. Jurnal Fakultas Keguruan dan Ilmu Pendidikan, 8(02), 23-24. https://ejurnal.bunghatta.ac.id/index.php/J FKIP/article/view/17296.

Nguyen, T. (2015). The Effectiveness of Online Learning: Beyond No Significant Difference and Future Horizons. MERLOT Journal of Online Learning and Teaching, 11(2), 309-319. https://www.researchgate.net/publication/ 308171318 The Effectiveness of Online Learning Beyond No Significant Diffe rence_and_Future_Horizons.

Nurdin \& Anhusadar, L. O. (2020). Efektivitas Pembelajaran Online Pendidik PAUD di Tengah Pandemi Covid 19. Jurnal Obsesi: Jurnal Pendidikan Anak Usia Dini, 5(1), 
686-697.

https://www.obsesi.or.id/index.php/obsesi /article/view/699.

Nurhidayat, D. (2020). Efektifitas E-learning sebagai Media Pembelajaran. JTR-Jurnal Tata Rias, 10(1), 26-35. http://journal.unj.ac.id/unj/index.php/jtr/ar ticle/view/14491.

Nur, M., Pradipta, G. D., \& Maliki, O. (2020). Efektivitas Pembelajaran Daring Mata Pelajaran PJOK Siswa Kelas IX di MTSN 2 Semarang Selama Pandemi Covid-19. Seminar Nasional KeIndonesiaan V, hlm. 108-125, Universitas PGRI Semarang. http://conference.upgris.ac.id/index.php/s nk/article/view/1139.

Pane, A. \& Dasopang, M. D. (2017). Belajar dan Pembelajaran. Jurnal Kajian Ilmu, 3(2), 333-352. http://jurnal.iainpadangsidimpuan.ac.id/index.php/f/article /view/945.

Panigrahi, R., Srivastava, P. R., \& Panigrahi, P. K. (2020). Effectiveness of E-learning: the Mediating Role of Student Engagement on Perceived

Learning Effectiveness. Electronic Journal of Elearning, 12(6), 154-167. https://www.emerald.com/insight/content/ doi/10.1108/ITP-07-2019-0380/full/html.

Panyajamorn, T., et al. (2018). Effectiveness of Elearning Design in Thai Public Schools. Malaysian Journal of Learning and Instruction, 15(1), 1-34. http://mjli.uum.edu.my/images/Vol15No1 June2018/a-1-34.pdf.

Pringgawidagda, S. (2002). Strategi Penguasaan Berbahasa. Yogyakarta: Adicita Karya Nusa.

Purwanto, N. (2002). Ilmu Pendidikan Teoritis dan Praktis. Bandung: Remaja Karya.

Ravitz, J. \& Blazevski, J. (2014). Assessing the Role of Online Technologies in ProjectBased Learning. Interdisciplinary Journal of Problem-Based Learning, 8(1), 4-10. https://doi.org/10.7771/1541-5015.1410.

Rohmawati, A. (2015). Efektivitas Pembelajaran. Jurnal Pendidikan Usia Dini, 9(1), 15-32. http://journal.unj.ac.id/unj/index.php/jpud /article/view/3491.

Rustiani, R., et al. (2019). Measuring Usable Knowledge: Teacher's Analyses of Mathematics for Teaching Quality and Student Learning. International Conference on Natural and Social Sciences (ICONSS) Proceeding Series, hlm. 239-245, Sekolah Tinggi Keguruan dan Ilmu Pendidikan Muhammadiyah Enrekang.

https://journals.sagepub.com/doi/abs/10.3 102/0002831212437853.

Setiaji, B. \& Jumadi, J. (2018). Developing Physics Subject-Spesific Pedagogy on Problem Based Learning Model Assisted By Elearning to Enhance Student's Scientific Literacy Skill. International Journal of Sciences: Basic and Applied Research (IJSBAR), 6(1), 59-70. https://www.gssrr.org/index.php/JournalO fBasicAndApplied/article/view/8933.

Sianturi, S. R. (2018). Meningkatkan Motivasi Belajar melalui Evaluasi E-learning pada Institusi Keperawatan di Jakarta dan Depok. Jurnal Pendidikan Keperawatan Indonesia, 4(2), 122-130. https://doi.org/10.17509/jpki.v4i2.11563.

Slameto. (2010). Belajar dan Faktor-faktor yang Mempengaruhinya. Jakarta: PT. Rineka Cipta.

Slavin, R. (2008). Psikologi Pendidikan Teori dan Praktek. Jakarta: PT Indeks.

Solihin, R., Muin, M. T., \& Iqbal, M. (2021). Analisis Efektivitas Pembelajaran Jarak Jauh pada Mahasiswa PGMI Stai AsySyukriyyah Tangerang. Jurnal AsySyukriyyah, 22(1), 52-59. https://doi.org/10.36769/asy.v22i1.139.

Solikha, E. (2018). Analisis Efektivitas Pembelajaran Sosiologi pada Siswa Kelas $X$ di Madrasah Aliyah Al-Anwar Pontianak. Jurnal Pendidikan dan Pembelajaran Khatulistiwa, 7(8), 5-7. https://jurnal.untan.ac.id/index.php/jpdpb/ article/view/27350.

Sugiyono. (2019). Metode Penelitian Kuantitatif, Kualitatif, dan $R \& D$. Bandung: Alfabeta. 
Suprijono, A. (2009). Cooperative Learning, Teori \& Aplikasi PAIKEM. Yogyakarta: Pustaka Pelajar.

Suryosubroto (2009). Proses Belajar Mengajar di Sekolah. Jakarta: PT Rienka Cipta.

Susanto, A. (2013). Teori Belajar dan Pembelajaran. Jakarta: Prenada Media Group.

Syarifudin, A. S. (2020). Impelementasi Pembelajaran Daring untuk Meningkatkan Mutu Pendidikan sebagai Dampak Diterapkannya Social Distancing. Jurnal Pendidikan Bahasa dan Sastra Indonesia Metalingua, 5(1), 31-34. https://doi.org/10.21107/metalingua.v5i1. $\underline{7072}$.

Wahyuddin, W. \& Nurcahaya, N. (2019). Efektivitas Pembelajaran Matematika melalui Pembelajaran Aktif Tipe Everyone is a Teacher Here (Eth) pada Siswa Kelas $X$ SMA Negeri 8 Takalar. Al Khawarizmi: Jurnal Pendidikan dan Pembelajaran Matematika, 2(1), 72-105. http://103.107.187.25/index.php/alkhawar izmi/article/view/4500.

Widiyono, A. (2020). Efektifitas Perkuliahan Daring (Online) pada Mahasiswa PGSD di Saat Pandemi Covid 19. Jurnal Pendidikan, 8(2), 169-177. https://www.researchgate.net/publication/ 343884475 Efektifitas Perkuliahan Dari ng_Online_pada_Mahasiswa_PGSD_di_S aat Pandemi_Covid 19.

World Health Organization. (2020). Coronavirus Disease 2019 (COVID-19) Situation Report 71. https://www.who.int/docs/defaultsource/coronaviruse/situationreports/20200331-sitrep-71-covid19.pdf?sfvrsn=4360e92b_8, diakses pada tanggal 15 Maret 2021.

Yohana, Muzakir, \& Dina, H. (2020). Efektivitas Pembelajaran Daring pada Program Studi Pendidikan Ekonomi Koperasi Fakultas Keguruan dan Ilmu Pendidikan Universitas Qamarul Huda Badaruddin. Jurnal Tirai Edukasi, 1(4), 1-8. http://jkqh.uniqhba.ac.id/index.php/tirai_e dukasi/article/view/185.

Yulianto, D. \& Nugraheni, A. S. (2021) Efektivitas Pembelajaran Daring dalam Pembelajaran Bahasa Indonesia. DECODE: Jurnal Pendidikan Teknologi Informasi, 1(1), 33-42. http://journal.umkendari.ac.id/index.php/d ecode/article/view/73.

Zahra, A. S. \& Wijayanti, S. (2020). Efektivitas Pembelajaran Basis Online di IAIN Tulungagung dengan Adanya Kebijakan Psychal Distancing Era Pandemi Covid 19. Jurnal Pendidikan, Bahasa dan Sastra, 8(1), 83-89. https://doi.org/10.25299/geram.2020.vol8 (1).5040.

Zhang, D., Zhou, L., \& Briggs, R. (2006). Instructional Video in E-learning: Assessing the Impact of Interactive Video on Learning Effectiveness. Journal Information \& Management, 43(1), 15-27. https://www.sciencedirect.com/science/art icle/abs/pii/S0378720605000170.

Zulkifli, N., Nurmayanti, N., \& Ferdiansyah, H. (2021). Efektifitas Media Pembelajaran Daring di Masa Pandemi Covid19. Edumaspul: Jurnal Pendidikan, 5(1), 71-77.

https://doi.org/10.33487/edumaspul.v5i1. 1123.

Zuraini, Z. \& Nurhayati, N. (2021). Efektifitas Pembelajaran E-learning di Era New Normal. Genta Mulia: Jurnal Ilmiah Pendidikan, 12(1), 130-136 https://www.ejournal.stkipbbm.ac.id/inde x.php/gm/article/view/563. 